\title{
Switched before birth
}

$\mathrm{T}$ wo babies - now grown men - switched at birth and left to grow up in the wrong families. When the story broke in late August, condemnation was swift. "Lives were stolen," said Manitoba's former aboriginal affairs minister, Eric Robinson, who called the switch "disgraceful" and "criminal." David Tait, one of the men who'd been raised by the wrong family, described it as "forty years gone." Federal health minister Jane Philpott said she was "deeply troubled" by the news and has agreed to meet with the men.

Both were raised by people who loved them and grew up within their own indigenous community. But they were not raised by their genetic parents and, worse, they were deprived of that knowledge for decades.

But why is it wrong when it happens in a hospital by accident, but okay when doctors are paid to do it? That is the question on the minds of some so-called "donor offspring" people created through the eggs or sperm of individuals they will never know.

"How can you be emotionally aghast about this," asks Barry Stevens,

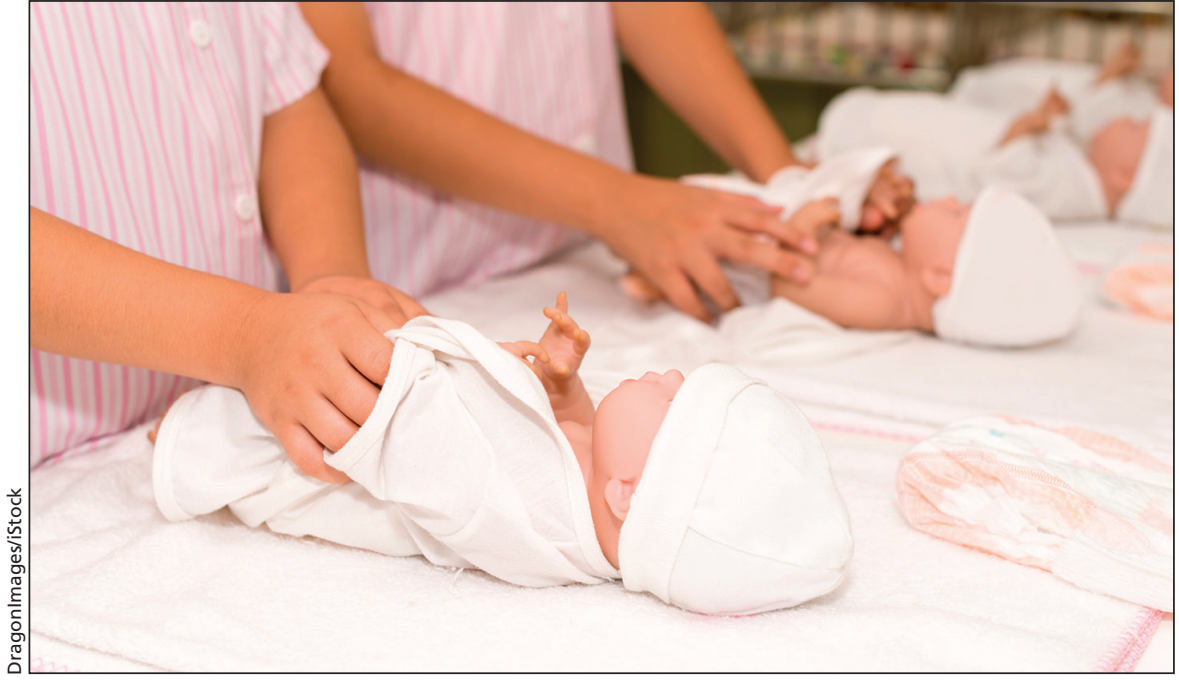

There is no duty to inform so-called donor offspring that their progenitors are not the people raising them.

"I think I was owed the right to not find out that way," says Hunter.

Under the law, however, he is not owed that right. Not only is there no duty to inform donor offspring that their progenitors are not the people raising them, but the fact does not need to be noted on the official registration of their birth. Donor offspring also do not have the right to obtain copies of any paper records pertaining to their

\section{Donor offspring do not have the right to obtain copies of paper records pertaining to their donors.}

who learned at age 18 that he was donor conceived, "and then say there's nothing wrong with deliberately making people who will have no opportunity to know where they come from?" Stevens, a Toronto filmmaker, made an award-winning film, Offspring, about his quest to find his sperm donor.

Rob Hunter was also an adult when he found out. He was drinking with his grandmother, when she accidentally let slip that the man he knew as his father wasn't biologically related to him, and that he'd been conceived with donor sperm at an Ontario clinic. donors. Olivia Pratten, a woman conceived in British Columbia via donor sperm, took that battle to court in 2010. She won, then lost on appeal.

The switches at birth in Manitoba appear to have been accidental. But donor gametes are swapped knowingly. Like the two Norway House, Manitoba men, Hunter had to suddenly reconfigure his identity. But he also had to face the fact that both his parents had lied to him and that doctors and other medical professionals were all in on the secret.

Doctors used to discourage parents from telling their children the truth, arguing that they would never find out. This is what Stevens', Pratten's and Hunter's parents were all advised. Professionals now typically encourage parents to tell early and often. Nevertheless, many parents still choose to conceal.

"I am amazed at how many patients will not disclose," Dr. Prati Sharma, a fertility doctor at the CReATe clinic in Toronto, told a September meeting of the Canadian Fertility and Andrology Society.

Stevens is baffled by how people seem to understand the situation of the Norway House men but cannot understand the yearnings of people like him. "If it's so meaningful to them - and it is — and so obviously meaningful to people watching and reading about this, why are you surprised it would be meaningful to offspring of gamete providers?"

Since its inception in 2000, more than 51000 people have signed up on the Donor Sibling Registry, an online database where half-siblings related through gamete donation - and sometimes their donors - can connect. To date, 13691 matches have been made. - Alison Motluk, Toronto, Ont. 